\title{
Praca dermatologa za kołem polarnym
}

\section{Barbara Gąsior-Chrzan}

\author{
University of Tromsoe, Norwegia
}

Dwa norweskie województwa leżące za kołem polarnym Troms i Finnmark, graniczący na wschodzie z Rosją, 1 stycznia 2020 roku połączono w jedno w wyniku reformy administracyjnej. Powierzchnia nowopowstałego województwa wynosi 74546 km², co stanowi $23 \%$ terytorium Norwegii. Obszar ten zamieszkiwało, według danych na dzień 1 stycznia 2021 roku, 242168 osób. Rdzenną ludnością Finnmarku są Lapończycy (Saamowie) i przybyli znacznie później Norwegowie. Obecnie kieruje się tam także cudzoziemców przydzielonych Norwegii przez Urząd Wysokiego Komisarza do Spraw Uchodźców przy ONZ. Są to głównie młodzi ludzie z terenów objętych wojną. Ich skóra jest wyraźnie ciemniejsza i grubsza niż rdzennych mieszkańców północnej Norwegii. Rezultatem jest mniejsza produkcja witaminy D i wynikające $\mathrm{z}$ tego konsekwencje zdrowotne. Obecnie łatwo się tam dostać samolotem, autobusem bądź samochodem. Jeszcze w latach 60. ubiegłego wieku nie było to takie proste. Ludność tych terenów musiała sobie radzić bez pomocy osiągnięć cywilizacyjnych dostępnych w pozostałej części Norwegii. Czas płynął wolniej, a szczególnie powoli w czasie nocy polarnej od listopada do lutego. Brak dróg, bardzo obfite śniegi i mrozy do $-50^{\circ} \mathrm{C}$ nie sprzyjały opuszczaniu domów, nawet w sytuacjach koniecznych. Nie było tam wówczas połączeń telefonicznych, nie przylatywały helikoptery. $W$ razie potrzeby pomocy szukano lokalnie.

Od tysiącleci bardzo ważną osobą w tej społeczności jest szaman - uzdrowiciel, healer. To on leczył stany nagłe i choroby przewlekłe. Leczył skutecznie. Nie zapisywał pigułek, zastrzyków i innych akcesoriów medyczno-farmakologicznych, które poleca nam współczesna medycyna akademicka. Tu nie było lekarzy i aptek, ale rosły zioła, które zbierano w czasie krótkiego polarnego lata, suszono i w razie potrzeby stosowano według zaleceń szamana lub własnego doświadczenia. Uzdrawiając, szaman wprowadzał się w trans, w czasie którego łączył się z siłami kosmicznymi, niewidzialnymi. Przywoływał te siły recytacją wersetów niezrozumiałych dla postronnych. Pomagały mu w tym dźwięki bębna, na którym sa wypisane tajemnicze znaki. Gdy dotarło tu chrześcijaństwo, jedynym słowem, które można było wyłowić słuchem pośród monotonnego mamrota- nia, było słowo "Jezus”. Szaman uzdrawiał w imię Jezusa. Gdy ktoś się niebezpiecznie zranił, krwawienia nie można było opanować i sytuacja stawała się krytyczna, możliwie jak najprędzej kontaktowano się z szamanem. Krwawienie natychmiast ustawało, pacjent nie musiał być przy tym obecny. Szamani leczą wszystkie choroby, także otyłość. Podobnie jak medycyna akademicka nie u wszystkich pacjentów są równie skuteczni. Niechętnie zajmują się nowotworami, gdyż wymagają one ogromnej energii i bardzo osłabiają szamana. Szaman jest pośrednikiem pomiędzy kosmosem - Duchem a pacjentem. Zdolności szamańskie otrzymuje się, przychodząc na świat, albo można je przekazać $\mathrm{w}$ rodzinie $\mathrm{z}$ pradziada na dziada, z ojca na syna. Osoba, której się je przekazuje, musi spełniać wysokie standardy moralne, gdyż mogą one być użyte przeciwnie - i szkodzić ludziom. Szaman może rzucić klątwę (gand) na pojedynczego człowieka, grupę ludzi, maszynę. Aby rzucić klątwę, niekoniecznie trzeba być szamanem. Wystarczy znać formułę zaklęcia.

Kilka lat temu głośna była sprawa „człowieka, który zatrzymał hurtigrutę". Hurtigruta to wielki statek (obecnie bardzo luksusowy) pływający między miastem Bergen na zachodnim wybrzeżu Norwegii a wyznaczonymi portami, docierający do Kirkenes, miasta niedaleko granicy z Rosją. Taka podróż zajmuje 6 dni, jest droga i cieszy się niesłabnącym zainteresowaniem turystów z całego świata. Na przedostatnim postoju w mieście Hammerfest na pokład wszedł Lapończyk i spacerując po statku, pluł obficie na piękne, puszyste dywany, którymi był wyścielony. Personel zwrócił mu uwagę na niestosowność takiego zachowania i przestrzegł, że zostanie usunięty. Lapończyk spojrzał niechętnie, coś wymamrotał i usiadł, czekając na odjazd hurtigruty. Gdy nadeszła godzina odjazdu, włączono motory, padła komenda: „cała naprzód”, ale nie można było odbić od kei. Wezwano mechaników, sprawdzono silniki. Wszystko technicznie było w porządku. Mimo to statek nie mógł ruszyć. Wydawało się, że jakaś niewidzialna siła trzyma go przy nabrzeżu. Po dłuższym czasie przypomniano sobie o plującym Lapończyku, podejrzewając go o rzucenie klątwy na hurtigrutę. Kapitan przepraszał go w ukłonach, mówiąc, że to zaszczyt mieć takiego pasażera. 


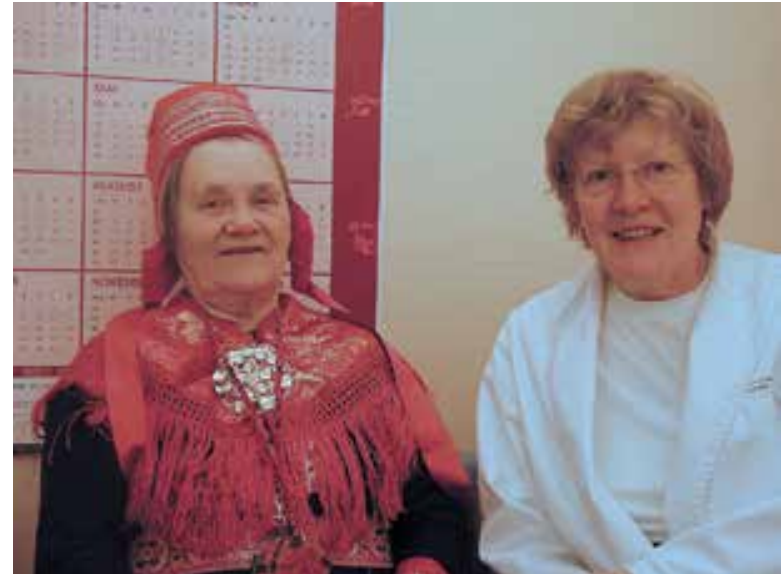

Rycina I. Autorka z Laponką

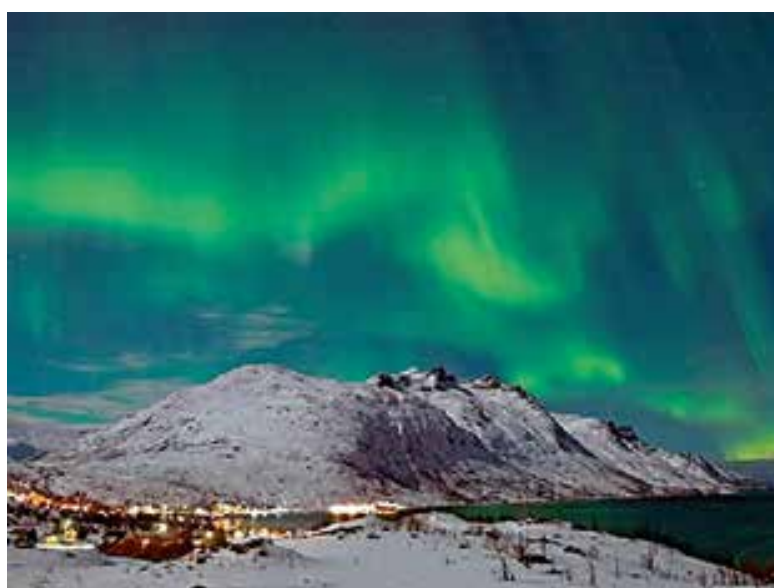

Rycina 2. Zorza polarna nad Finnmarkiem, aut. Marek Michalski

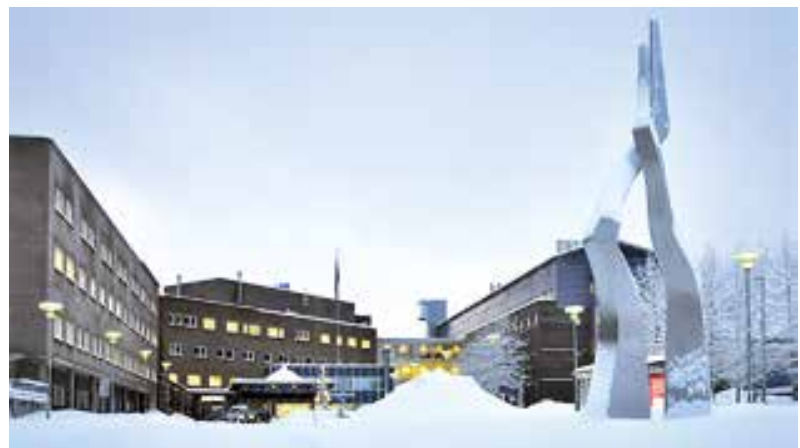

Rycina 3. Szpital Uniwersytecki w Tromsø, aut. Marek Michalski

Prosił o wybaczenie przykrości, którą mu sprawił personel i o cofnięcie klątwy. Lapończyk spojrzał przyjaźniej na kapitana, coś zamruczał pod nosem i hurtigruta ruszyła w dalszą podróż.

Z czasem zbudowano tu drogi, lotniska. Przybyli lekarze specjaliści, zbudowano szpitale z nowoczesnym sprzętem. Od kilku lat w lokalnych szpitalach i przychodniach Finnmarku uczy się z dużym powodzeniem studentów medycyny z Uniwersytetu w Tromsø. Dzieci szamanów studiują na uniwersytetach, piszą książki, doktoryzują się także z szamanizmu.

Przez kilka lat raz w miesiącu 2-3 dni pracowałam w Finnmarku jako dermatolog. Zgłaszali się pacjenci z różnymi chorobami skory, czasem bardzo rzadkimi. Kiedyś przyszli rodzice z dwuletnią dziewczynką chorującą na atopowe zapalenie skóry. Ojciec, dużo starszy od matki dziecka, poinformował mnie, że zasięgano porady szamana, co dziecku pomogło, ale choroba powróciła. Oni słyszeli o mnie i oczekują, że ja zatrzymam egzemę. Nie czułam się komfortowo. Moje możliwości terapeutyczne sprowadzały się do zapisania długopisem paru słów - znaków na kartce papieru zwanej receptą. Czy to wystarczy do zatrzymania choroby? Czy tubka maści działa silniej niż siły kosmiczne? Już ich potem nie widziałam.

Mijają wieki. W noce polarne nad Finnmarkiem szaleją wichury lub przy $-50^{\circ} \mathrm{C}$ niebo jarzy się gwiazdami i przebiegają po nim zorze polarne, rozjaśniając śnieżne pustynie. Przenikają się tutaj dwa światy: ten racjonalny, nowoczesny $\mathrm{z}$ tym archaicznym, istniejącym od stworzenia świata. Chorzy szukają pomocy u lekarzy, ale nie zapominają o swoich szamanach. Szamanizm jest integralną i ważną częścią kultury północnej Norwegii. 